\title{
Comparison of the effects of the three major tyrosine kinase inhibitors as first-line therapy for non-small-cell lung cancer harboring epidermal growth factor receptor mutations
}

\author{
Chih-Yen Tu ${ }^{1,2,3, *}$, Chuan-Mu Chen ${ }^{1, *}$, Wei-Chih Liao ${ }^{2,5,6}$, Biing-Ru Wu ${ }^{2}$, Chih-Yu \\ Chen $^{2,6}$, Wei-Chun Chen ${ }^{2,6}$, Te-Chun Hsiaa ${ }^{2,4,5}$, Wen-Chien Cheng ${ }^{2}$ and Chia-Hung \\ Chen $^{2,4,5,7}$ \\ ${ }^{1}$ Department of Life Sciences, and Agricultural Biotechnology Center, National Chung Hsing University, Taichung, Taiwan \\ ${ }^{2}$ Division of Pulmonary and Critical Care Medicine, Department of Internal Medicine, China Medical University Hospital, \\ Taichung, Taiwan \\ ${ }^{3}$ School of Medicine, China Medical University, Taichung, Taiwan \\ ${ }^{4}$ Department of Respiratory Therapy, China Medical University, Taichung, Taiwan \\ ${ }^{5}$ Graduate Institute of Clinical Medical Science, China Medical University, Taichung, Taiwan \\ ${ }^{6}$ Department of Internal Medicine, Hyperbaric Oxygen Therapy Center, China Medical University, Taichung, Taiwan \\ ${ }^{7}$ Taiwan Clinical Trial Consortium for Lung Diseases (TCOC), Taichung, Taiwan \\ *These authors contributed equally to this work \\ Correspondence to: Wei-Chih Liao, email: weichih.liao@gmail.com \\ Chia-Hung Chen, email: hsnu758@gmail.com
}

Keywords: EGFR-mutated lung adenocarcinoma; gefitinib; erlotinib; afatinib; progression-free survival Received: August 21, 2017 Accepted: January 25, 2018 Epub: February 04, 2018 Published: May 11, 2018

Copyright: Tu et al. This is an open-access article distributed under the terms of the Creative Commons Attribution License 3.0 (CC BY 3.0), which permits unrestricted use, distribution, and reproduction in any medium, provided the original author and source are credited.

\section{ABSTRACT}

Introduction: Patients with advanced lung adenocarcinoma harboring epidermal growth factor receptor (EGFR)-activating mutations have good response rate and longer progression-free survival (PFS) when treated with the tyrosine kinase inhibitors (TKI) compared with platinum-based chemotherapy. However, studies comparing the effectiveness of these drugs as first-line therapy in such patients are limited.

Results: We analyzed 422 patients with EGFR-mutated advanced lung adenocarcinoma receiving first-line gefitinib $(n=195,46.2 \%)$, erlotinib $(n=123$, $29.1 \%)$, or afatinib $(n=104,24.6 \%)$. The PFS of the afatinib group was longer (12.2 months) than that of the gefitinib group $(9.8$ months $)(p=0.035)$ but similar to that of the erlotinib group (11.4 months) $(p=0.38)$. In patients without brain metastasis (BM), subgroup analysis showed that the afatinib group had significantly longer PFS (13.1 months) than erlotinib (11.7 months) and gefitinib (9.8 months) groups $(p=0.010)$. Patients with exon 19 deletions in the afatinib and erlotinib groups had potentially long PFS $(p=0.073)$. Efficacy of afatinib was similar between the $30 \mathrm{mg}$ and $40 \mathrm{mg}$ arms (median PFS 16.1 months vs. 10.3 months; $p=0.923$ ).

Conclusions: Afatinib may be the optimal EGFR-TKI for advanced lung adenocarcinoma harboring EGFR-activating mutations, particularly in the absence of BM. Patients with exon 19 deletions taking afatinib had potentially long PFS. An afatinib dose of $\mathbf{3 0}$ and $\mathbf{4 0} \mathbf{~ m g}$ has similar effect.

Methods: We conducted this retrospective study at a single medical center from January 2013 to March 2017 and used PFS to evaluate the effectiveness of gefitinib, erlotinib, and afatinib in patients with advanced lung adenocarcinoma harboring EGFR mutations. 


\section{INTRODUCTION}

Advanced non-small-cell lung cancer (NSCLC) that harbors characteristic mutations in epidermal growth factor receptor (EGFR) is highly sensitive to EGFR tyrosine kinase inhibitors (TKIs) [1]. The frequency of EGFR mutations varies widely across different populations, with increased incidence of such mutations in nonsmokers [2], women [3], adenocarcinomas [4, 5], and the Asian population [6]. The incidence of EGFR mutations was approximately 50\% and $10-15 \%$ among Asian and Caucasian NSCLC patients, respectively [7].

Three major EGFR-TKIs, namely, gefitinib, erlotinib, and afatinib, have been approved for NSCLC with EGFR mutations since 2009. Gefitinib and erlotinib are the first-generation EGFR-TKIs that reversibly inhibit the kinase activity of overall EGFR (HER1). Afatinib, a second-generation EGFR-TKI, covalently and irreversibly binds to the intracellular tyrosine kinase domain and is a highly selective blocker of the pan-ErbB family [8]. It inhibits intracellular phosphorylation, preventing further downstream signaling and resulting in cell death. The three major EGFR-TKIs had demonstrated superior response rate (RR) and significantly prolonged progression-free survival (PFS) but not in overall survival (OS) in phase III trial in patients with NSCLC harboring EGFR mutations compared with platinum-based chemotherapy doublets $[4,5,9-16]$. Interestingly, the combined analyses of LUXLung 3 and LUX-Lung 6 indicated that afatinib had a statistically significant benefit in OS in patients with exon 19 deletion [17]. Interest on which EGFR-TKI should be the best choice as first-line therapy in such patients has been growing.

Few clinical trials conducted a head-to-head comparison of EGFR-TKIs. Two phase III trials that directly compared erlotinib and gefitinib were conducted in Asian patients; these two agents are comparably effective in previously treated EGFR mutation-positive NSCLC patients $[18,19]$. In the phase IIb LUX-Lung 7 trial comparing gefitinib and afatinib as first-line treatment of EGFR-mutated NSCLC patients, afatinib significantly improved PFS compared with gefitinib (11.0 months vs. 10.9 months; HR: $0.73 ; p=0.017$ ) [20], and no significant difference in OS was noted in a subsequent report [21].

To date, no trial has compared these three TKIs together. A limited number of retrospective studies compared these three TKIs. Kuan et al. reported that PFS was significantly longer in patients who received afatinib and erlotinib compared with those who received gefitinib as first-line treatment of common EGFR-mutated NSCLC [22]. Meanwhile, Krawczyk et al. reported that the effectiveness (treatment response, median PFS, and OS) of these three TKIs was not significantly different in patients with both common and rare EGFR mutations [23]. Therefore, we conducted a retrospective study to analyze the effectiveness of these three EGFRTKIs as first-line therapy in NSCLC patients with EGFR mutations.

\section{RESULTS}

\section{Patient characteristics}

A total 1951 patients were screened between January 2013 and March 2017, 1006 of whom had newly diagnosed or recurrent stage IIIb/IV lung adenocarcinoma. Among them, 457 patients had tumors that were EGFR mutation negative (wild-type EGFR). A total of 63 patients were excluded from the study because of incomplete data, and 64 were excluded in the analysis their treatment lasted less than 30 days. Four hundred and twenty-two patients with EGFR mutation-positive advanced lung adenocarcinoma received gefitinib $(n=195)$, erlotinib $(n=123)$, or afatinib $(n=104)$ as first-line treatment (Figure 1). Baseline characteristics of the patients are shown in Table 1. Significant differences were noted in gender $(p=0.043)$ and age $(p=0.044)$, while the other factors were not statistically significant between the treatment groups. The proportion of elderly patients $(56.9 \%)$ and women $(69.7 \%)$ was higher in the gefitinib group than in the other two groups (Figure 2A). However, the result showed a slight difference in the composite of the types of EGFR mutation in each arm $(p=0.058)$. The afatinib group had a high percentage of exon 19 deletions $(55.8 \%)$ and rare mutation $(22.1 \%)$ and a low percentage of Leu858Arg (22.1\%) (Figure 2B). We performed Cox regression analysis to adjust the variations.

\section{Progression-free survival}

The median PFS of the three EGFR TKI patient groups (gefitinib, erlotinib, and afatinib) was 9.8, 11.4, and 12.2 months, respectively (Figure 3 ). Patients receiving afatinib had a significantly longer PFS than did patients receiving gefitinib (median, 12.2 vs. 9.8 months; $p=0.035$; Figure 4A) but had similar PFS with those receiving erlotinib (median, 12.2 vs. 11.4 months; $p=0.38$; Figure 4B) in the entire study population. Analysis results based on the type of EGFR mutations showed that PFS was not significantly different among the three EGFR TKIs. However, in patients with exon 19 deletions, the afatinib or erlotinib group had slightly longer PFS than the gefitinib group (12.2 vs. 12.0 vs. 9.4 months; $p=0.074$; Figure 5A, 5B). In patients with rare EGFR mutation, the afatinib group (19.7 months) had longer PFS than the erlotinib (7.0 months) and gefitinib (7.0 months) groups, although the difference was not statistically significant (19.7 months vs. 7.0 months vs. 7.0 months, respectively; $p=0.506$; Figure 5C).

PFS was also not significantly different among in subgroups that were based on such factors as gender ( $p=0.404$ for male and $p=0.078$ for female), smoking 
status ( $p=0.12$ for smokers and $p=0.148$ for nonsmokers), and presence of brain metastasis $(\mathrm{BM})(p=0.376$; Figure 6A). However, in the subgroup with no BM, afatinib was associated with significantly longer median PFS than erlotinib or gefitinib (13.1 months, 11.7 months, and 9.8 months, respectively; $p=0.010$; Figure $6 \mathrm{~B}$ ).

We also evaluated the influence of afatinib dose reduction on PFS. The median PFS was compared in patients in whom afatinib dose was reduced to $30 \mathrm{mg}$ vs. those whose doses were maintained at $40 \mathrm{mg}$. The results indicated that the median PFS was similar in patients in whom the dose was reduced to $30 \mathrm{mg}$ (16.1 months) vs. those remaining at $40 \mathrm{mg}$ (10.3 months) $(p=0.923$; Figure 7).

\section{DISCUSSION}

Our study showed that in NSCLC patients with EGFR mutations, afatinib was superior to gefitinib but had similar effectiveness to erlotinib. In the patient subgroup with no BM, afatinib provided significantly longer PFS than erlotinib or gefitinib. Patients with exon 19 deletions and rare mutations treated with afatinib had slightly longer PFS than those receiving the first-generation TKIs. Moreover, the effectiveness of afatinib was similar between the doses $30 \mathrm{mg}$ and $40 \mathrm{mg}$.

The result of the current study was consistent with the findings of LUX-Lung 7 trial. Afatinib significantly improved PFS (11.0 month and 10.9 months; HR: 0.73; $p=0.017)$ and time to treatment failure (13.7 months and 11.5 months; HR: $0.73 ; p=0.007)$ compared with gefitinib. [20] Our study even indicated that afatinib was associated with significantly longer PFS compared with erlotinib or gefitinib (13.1, 11.7, and 9.8 months, respectively; $p=0.010$ ) in the analysis of the patient subgroup with no BM. Such result may be explained by the different mechanisms of action between first-generation and second-generation EGFR-TKIs. The first-generation EGFR-TKIs reversibly bind to and inhibit EGFR signaling, while the second-generation EGFR-TKIs irreversibly binds to and blocks signaling from the homoor heterodimers of pan-ErbB family receptors [8].

EGFR-TKIs for the treatment of brain metastases (BM) in patients with EGFR mutation-positive NSCLC has been receiving increasing attention. A phase II study indicated a favorable response of BM to gefitinib. The response rate (RR), median PFS, and median OS for BM were $87.8 \%, 14.5$ months, and 21.9 months, respectively [24]. A retrospective study showed that erlotinib is effective in BM from NSCLC with EGFR activating mutations in exons 19 or 21 . The RR for BM, the median time to progression in the brain, and median OS were $82.4 \%, 11.7$ months, and 12.9 months, respectively [25]. The LUX-Lung 3 and 6 trial also showed the superiority of afatinib over chemotherapy in patients with EGFR mutation-positive NSCLC and BM (11.1 vs. 5.4 months;
HR: $0.54 ; p=0.1378)$ and (8.2 vs. 4.7 months; HR: 0.47; $p=0.1060)$ [26]. Head-to-head comparisons among gefitinib, erlotinib, and afatinib for patients with BM are yet to be conducted. In the present study, no significant difference was noted in PFS in patients treated with these drugs. The median PFS of patients treated with gefitinib, erlotinib, and afatinib was 8.9, 7.2, and 9.9 months, respectively $(p=0.367)$. The median PFS in our results was shorter than that in previous studies, which may be due to a high percentage of rare EGFR mutations in our study (gefitinib: $7 \%$, erlotinib: $7 \%$, and afatinib: $21 \%$ ).

The types of EGFR mutation may influence the effectiveness of EGFR-TKIs; patients with exon 19 deletions treated with gefitinib and erlotinib had longer survival than did patients with L858R mutation treated with the same medications [27-29]. A meta-analysis of 13 studies showed that exon 19 deletions might be associated with longer PFS compared with L858 mutations [30]. From this meta-analysis, afatinib showed higher efficacy in patients harboring exon 19 deletion than those with L858R mutation (HR: $0.49 ; p=0.108$ ) compared with gefitinib (HR: $0.76 ; p=0.244$ ) and erlotinib (HR: 0.53; $p=0.264)$. The results of the pooled LUX-Lung 3 and 6 analysis showed that afatinib had a statistically significant benefit for OS in patients with exon 19 deletions compared with standard chemotherapy [17]. Our study showed that afatinib and erlotinib had a similar trend of longer PFS than gefitinib in patients with exon 19 deletion $(12.2,12.0$, and 9.4 months, respectively; $p=0.074)$, but no difference in patients with L858R mutation (11.7, 10.9, and 10.4 months, respectively; $p=0.721)$. These difference may be explained by the following reasons: (1) T790M mutation, which is associated with primary and acquired TKI resistance, might occur more frequently for L858R, and L858R can coexist more frequently with other rare EGFR mutations, affecting the EGFR kinase sensitivity to TKIs; (2) exon 19 deletion might be more actively inhibited by EGFR TKIs because of an increased affinity for these than L858R mutations [30].

The present study also showed that afatinib (19.7 months) causes potentially longer PFS than erlotinib (7.0 months) and gefitinib (7.0 months) in patients with rare EGFR mutations, although no statistically significant difference was noted, which may be due to the less number of patients in this study. Chiu et al. reported that the median PFS was 7.7 months in patients with rare mutations (G719X/L861Q/S768I) after first-generation EGFR-TKI treatment [31]. Yang et al. indicated that the median PFS of patients harboring these rare mutations (G719X/L861Q/S768I) treated with afatinib was 10.7 months [32]. According to these two studies, afatinib may be a first-choice EGFR-TKI for patients with rare EGFR mutations, particularly G719X, L861Q, and S768I.

The most common adverse events (AEs) of these three major EGFR-TKIs include skin rash, stomatitis, paronychia, and diarrhea, which are manageable with 
Table 1: Baseline characteristics of NSCLC patients according to EGFR-TKIs

\begin{tabular}{|c|c|c|c|c|}
\hline & Gefitinib & Erlotinib & Afatinib & $P$ ylu \\
\hline & $N=195$ & $N=123$ & $N=104$ & $P$ value \\
\hline $\begin{array}{l}\text { Sex } \\
\text { Men } \\
\text { Women }\end{array}$ & $\begin{array}{l}59(30.3) \\
136(69.7)\end{array}$ & $\begin{array}{l}54(43.9) \\
69(56.1)\end{array}$ & $\begin{array}{l}39(37.5) \\
65(62.5)\end{array}$ & 0.043 \\
\hline $\begin{array}{l}\text { Age (years) } \\
<65 \\
>65\end{array}$ & $\begin{array}{c}84(43.1) \\
111(56.9)\end{array}$ & $\begin{array}{l}68(55.3) \\
55(44.7)\end{array}$ & $\begin{array}{l}58(55.8) \\
46(44.2)\end{array}$ & 0.044 \\
\hline $\begin{array}{l}\text { Smoking } \\
\text { Never } \\
\text { Current or ever }\end{array}$ & $\begin{array}{l}147(75.4) \\
48(24.6)\end{array}$ & $\begin{array}{l}92(74.8) \\
31(25.2)\end{array}$ & $\begin{array}{l}86(82.7) \\
18(17.3)\end{array}$ & 0.446 \\
\hline $\begin{array}{l}\text { BMI } \\
<20 \\
>20\end{array}$ & $\begin{array}{l}27(13.8) \\
168(86.2)\end{array}$ & $\begin{array}{c}21(17.1) \\
102(82.9)\end{array}$ & $\begin{array}{l}17(16.3) \\
87(83.7)\end{array}$ & 0.713 \\
\hline $\begin{array}{l}\text { EGFR mutation } \\
\text { Del19 } \\
\text { L858R }\end{array}$ & $\begin{array}{l}87(44.6) \\
94(48.2)\end{array}$ & $\begin{array}{c}48(39) \\
63(51.2)\end{array}$ & $\begin{array}{l}58(55.8) \\
23(22.1)\end{array}$ & 0.058 \\
\hline $\begin{array}{l}\text { Clinical stage } \\
\text { IIIb } \\
\text { IV }\end{array}$ & $\begin{array}{c}9(4.6) \\
186(95.4)\end{array}$ & $\begin{array}{c}3(2.4) \\
120(97.6)\end{array}$ & $\begin{array}{c}3(2.9) \\
101(97.1)\end{array}$ & 0.543 \\
\hline $\begin{array}{l}\text { ECOG PS } \\
0 \& 1 \\
>1\end{array}$ & $\begin{array}{c}164(84.1) \\
31(15.9)\end{array}$ & $\begin{array}{c}109(88.6) \\
14(11.4)\end{array}$ & $\begin{array}{c}93(89.4) \\
11(10.6)\end{array}$ & 0.332 \\
\hline $\begin{array}{l}\text { Baseline brain } \mathrm{m} \\
\text { Absence } \\
\text { Presence }\end{array}$ & $\begin{array}{c}161(82.6) \\
34(17.4)\end{array}$ & $\begin{array}{c}105(86.1) \\
17(13.9)\end{array}$ & $\begin{array}{l}82(78.8) \\
22(21.2)\end{array}$ & 0.360 \\
\hline
\end{tabular}

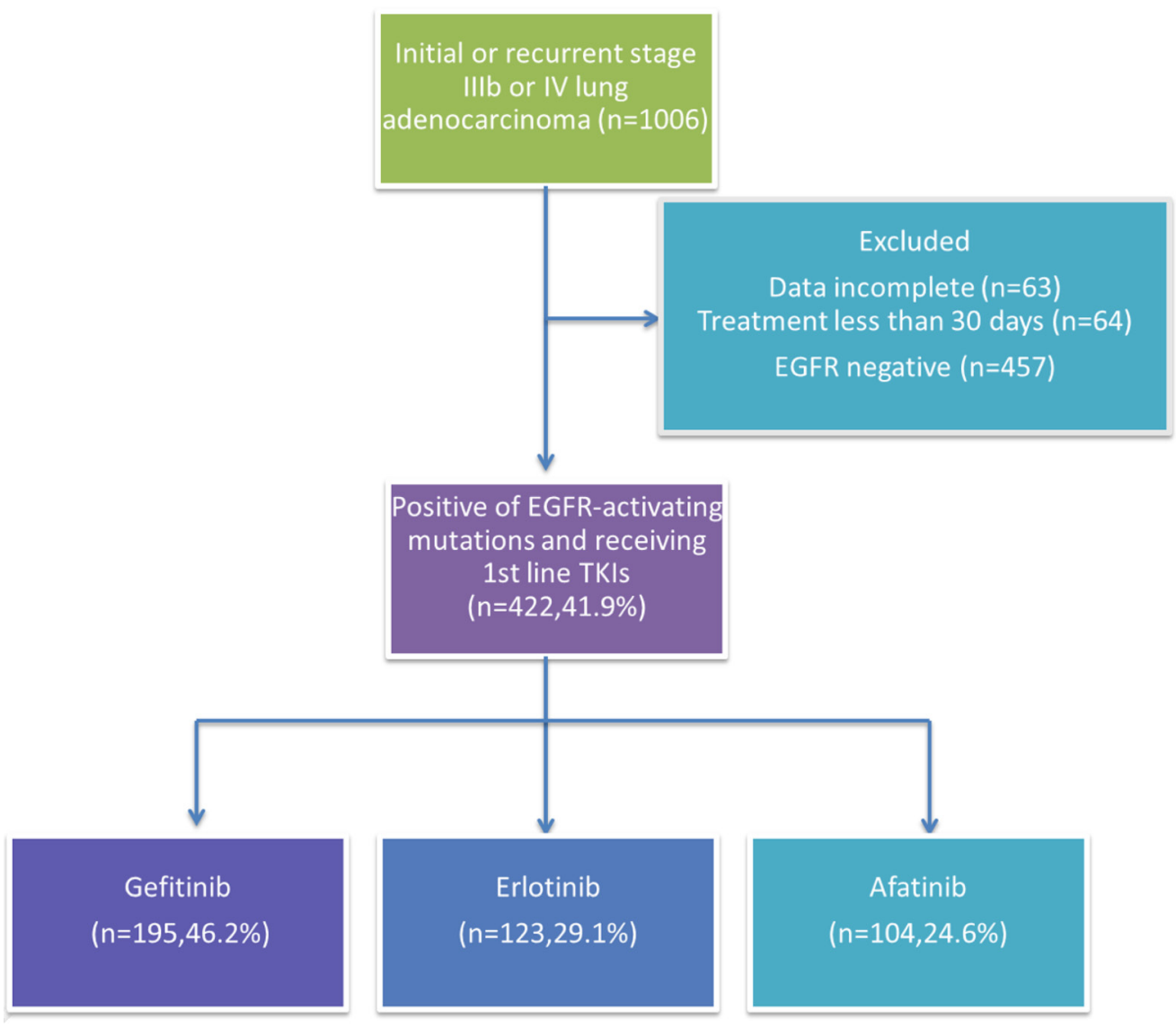

Figure 1: Patient disposition. 
A

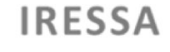

a Male "Female

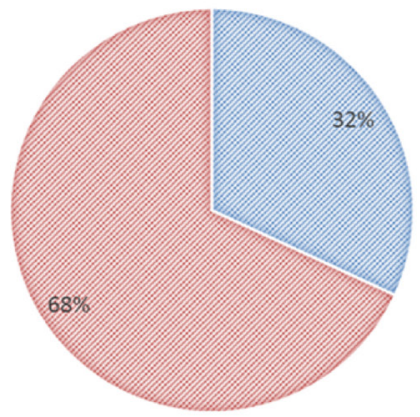

B

IRESSA

w Exon 19 w L858 w rare mutation

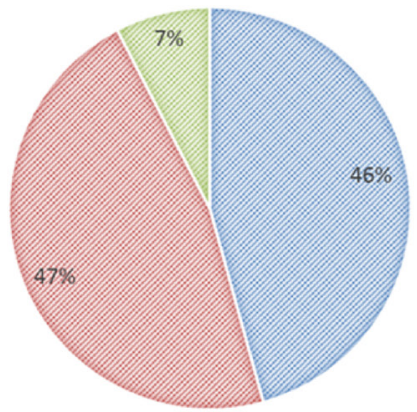

TARCEVA

« Male a Female

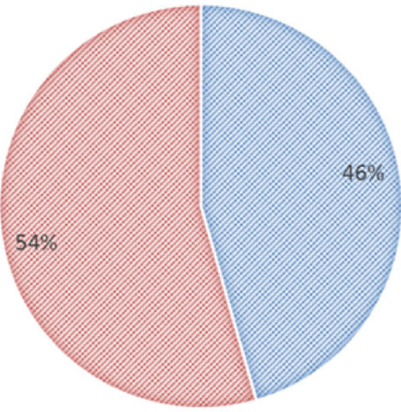

TARCEVA

Æxon $19 \approx$ L858 w rarmuation

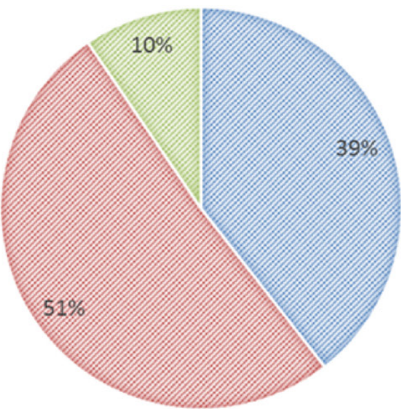

GIOTRIF

» Male a Female

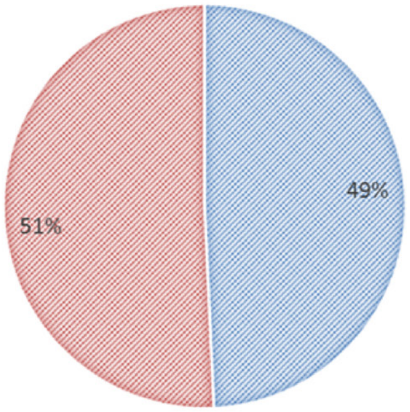

GIOTRIF

Exon 19 : L858 arare mutation

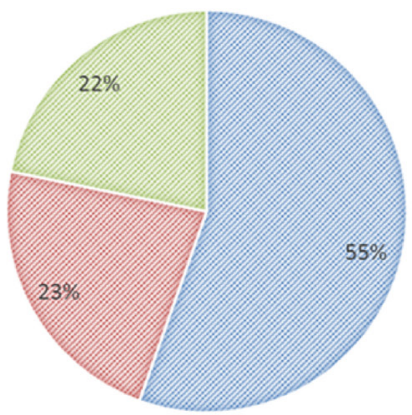

Figure 2: The three EGFR-TKIs proportions by (A) gender (B) the type of EGFR mutations.

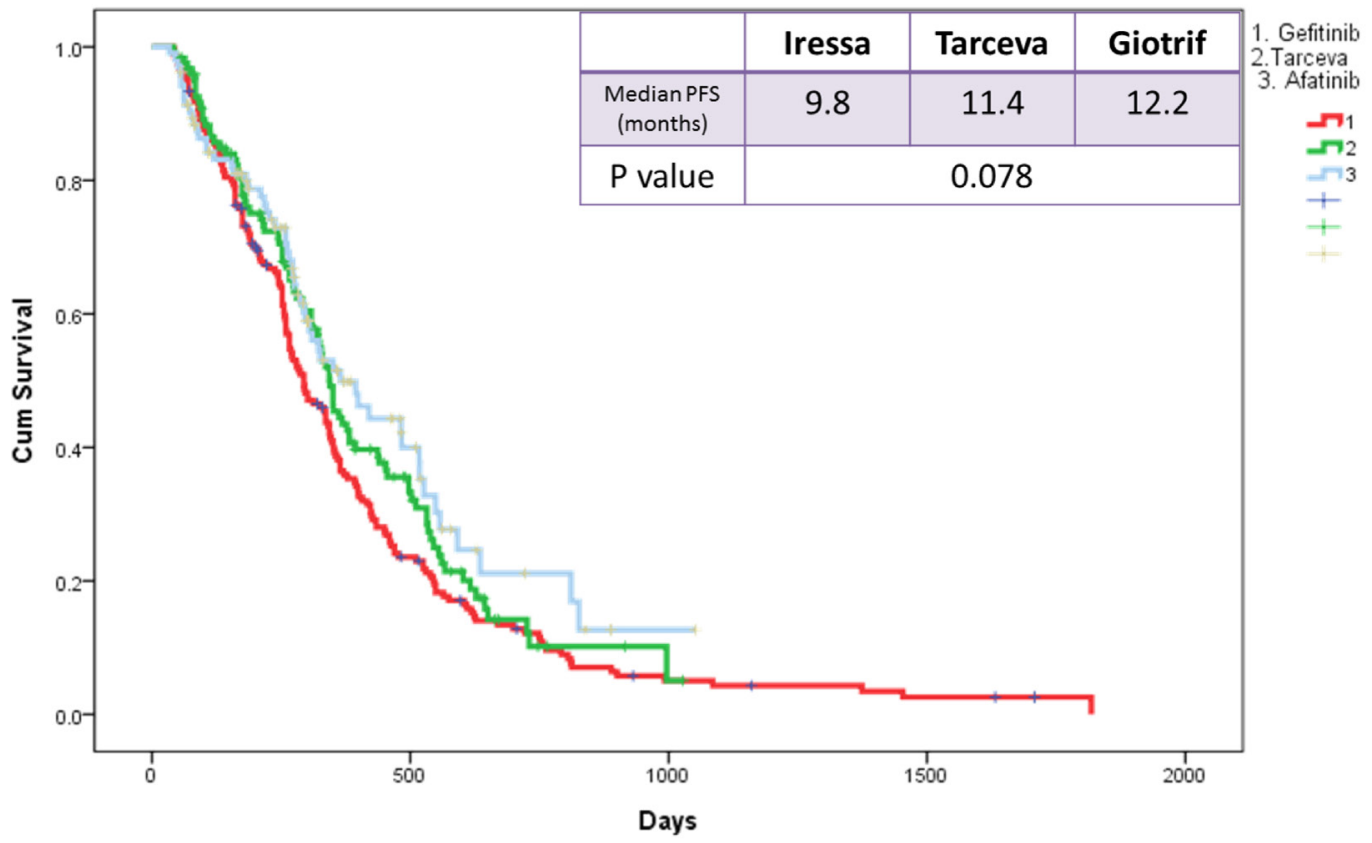

Figure 3: Kaplan-Meier survival curves of progression-free survival in patients received gefitinib, erlotinib, and afatinib. 


\begin{tabular}{|c|c|c|}
\hline & Iressa & Giotrif \\
\hline $\begin{array}{c}\text { Median PFS } \\
\text { (months) }\end{array}$ & 9.8 & 12.2 \\
\hline HR (95\%Cl) & \multicolumn{2}{|c|}{$0.72(0.54-0.97)$} \\
\hline P value & \multicolumn{2}{|c|}{0.035} \\
\hline
\end{tabular}

\begin{tabular}{|c|c|c|}
\hline & Tarceva & Giotrif \\
\hline $\begin{array}{c}\text { Median PFS } \\
\text { (months) }\end{array}$ & 11.4 & 12.2 \\
\hline HR (95\%Cl) & \multicolumn{2}{|c|}{$0.87(0.62-1.20)$} \\
\hline P value & \multicolumn{2}{|c|}{0.38} \\
\hline
\end{tabular}

A

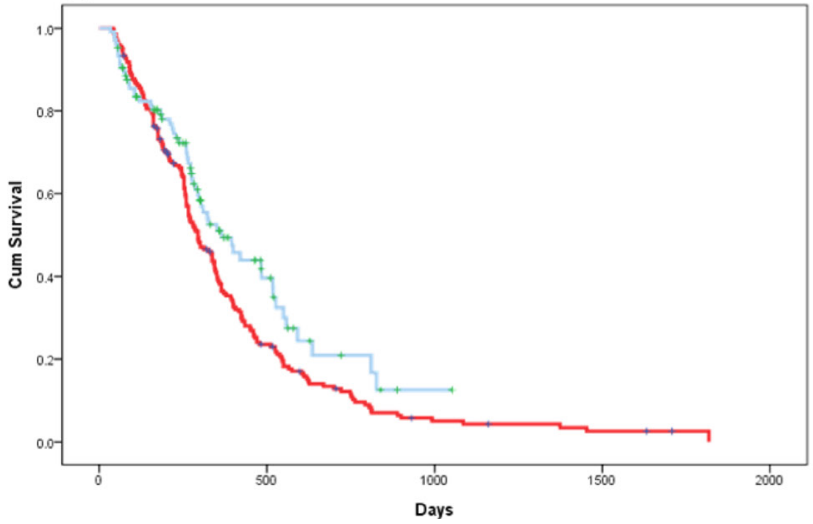

B

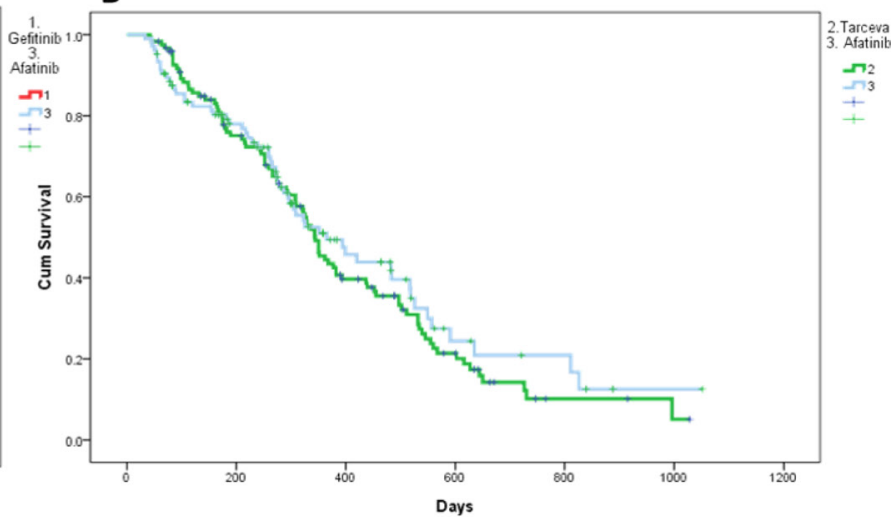

Figure 4: Kaplan-Meier survival curves of progression-free survival in patients who received (A) gefitinib and afatinib and (B) erlotinib and afatinib.
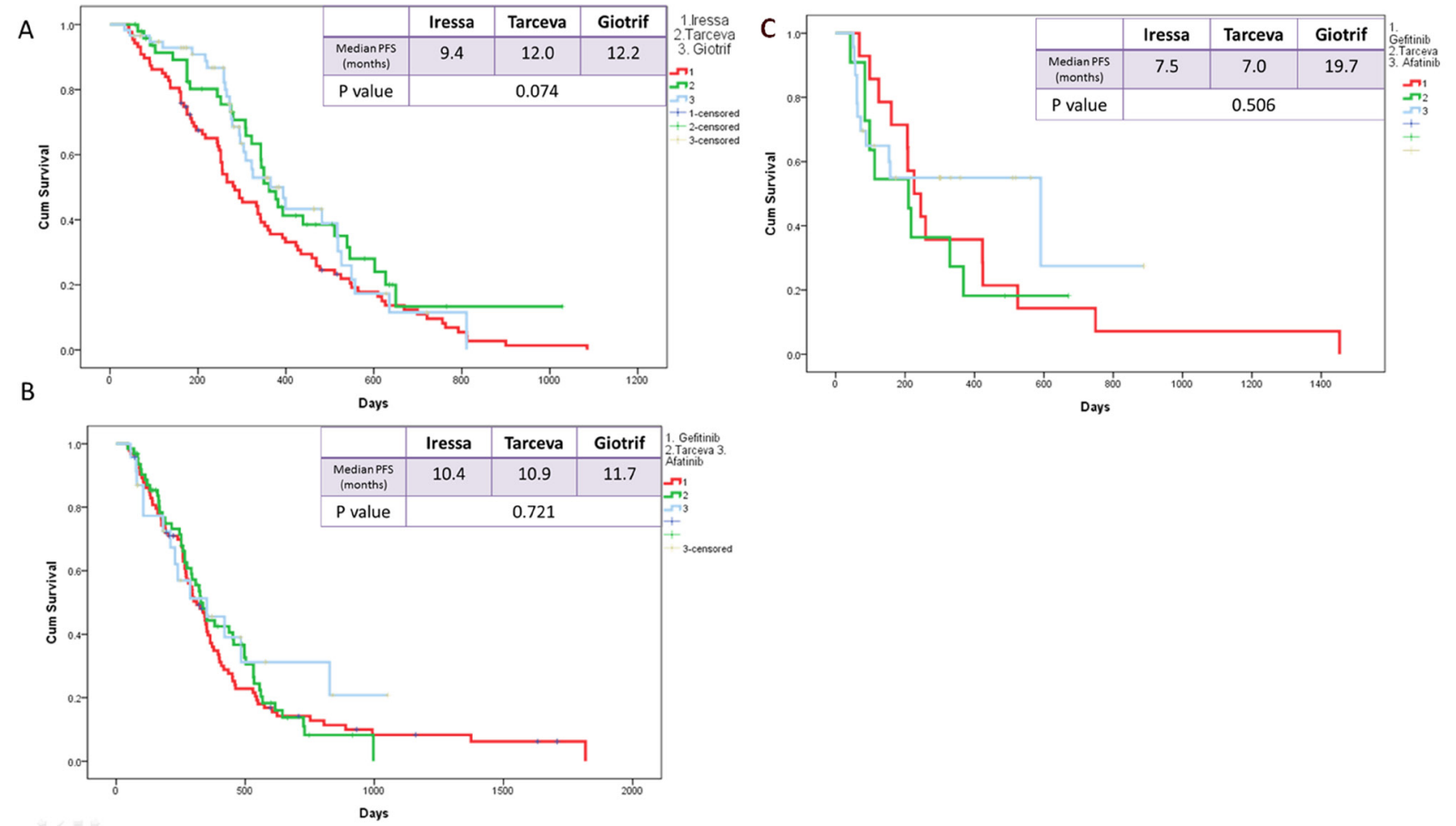

Figure 5: Kaplan-Meier survival curves of progression-free survival in patients who received gefitinib, erlotinib, and afatinib (A) in exon 19 deletions (B) in Leu858Arg (C) rare mutations. 
treatment interruptions or dose reduction and best supportive care [33]. We assessed the effectiveness of tolerability-reduced afatinib dose, and the median PFS was found to be similar between patients in whom the dose was reduced to $30 \mathrm{mg}$ (16.1 months) and those remaining at 40 $\mathrm{mg}(10.3$ months $)(p=0.923)$. The result was consistent with that of the LUX-Lung 3 and 6 studies (LL3: $11.3 \mathrm{vs.}$ 11.0 months; HR: 1.25 and LL6: 12.3 vs. 11.0 months; HR: 1.00) [34]. These results indicate that dose adjustment does not only has no impact on therapeutic efficacy but also reduces afatinib-related AEs.

We acknowledge some limitations in our study. First, this was a retrospective analysis, and some bias may be present in our study. Second, the numbers of patients with rare EGFR mutation varied among the three arms, and the sample size of each arm was small, which may result in no statistical significance. Third, we did not identify the type of rare mutations; the effectiveness of EGFR-TKIs is highly

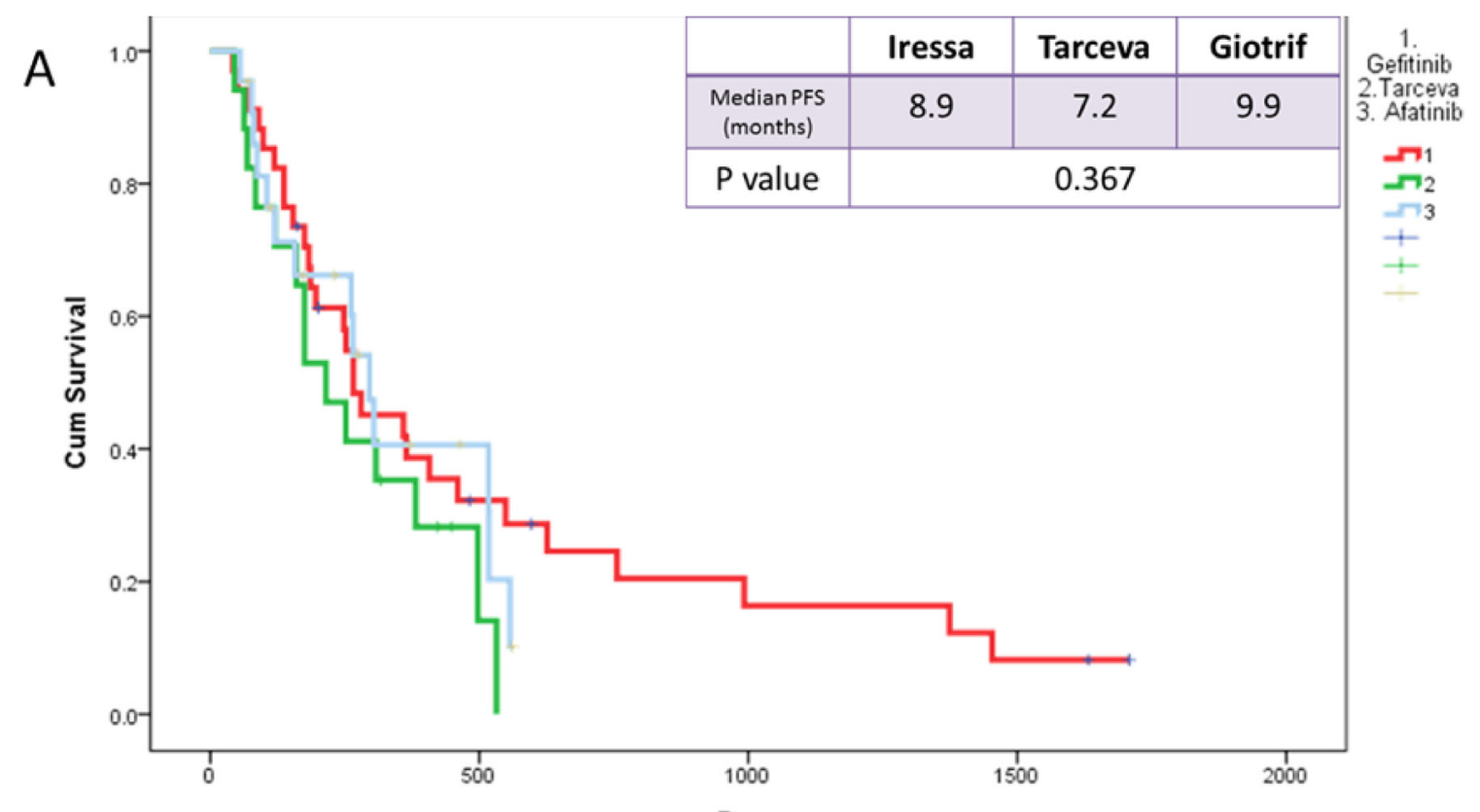

B

Days

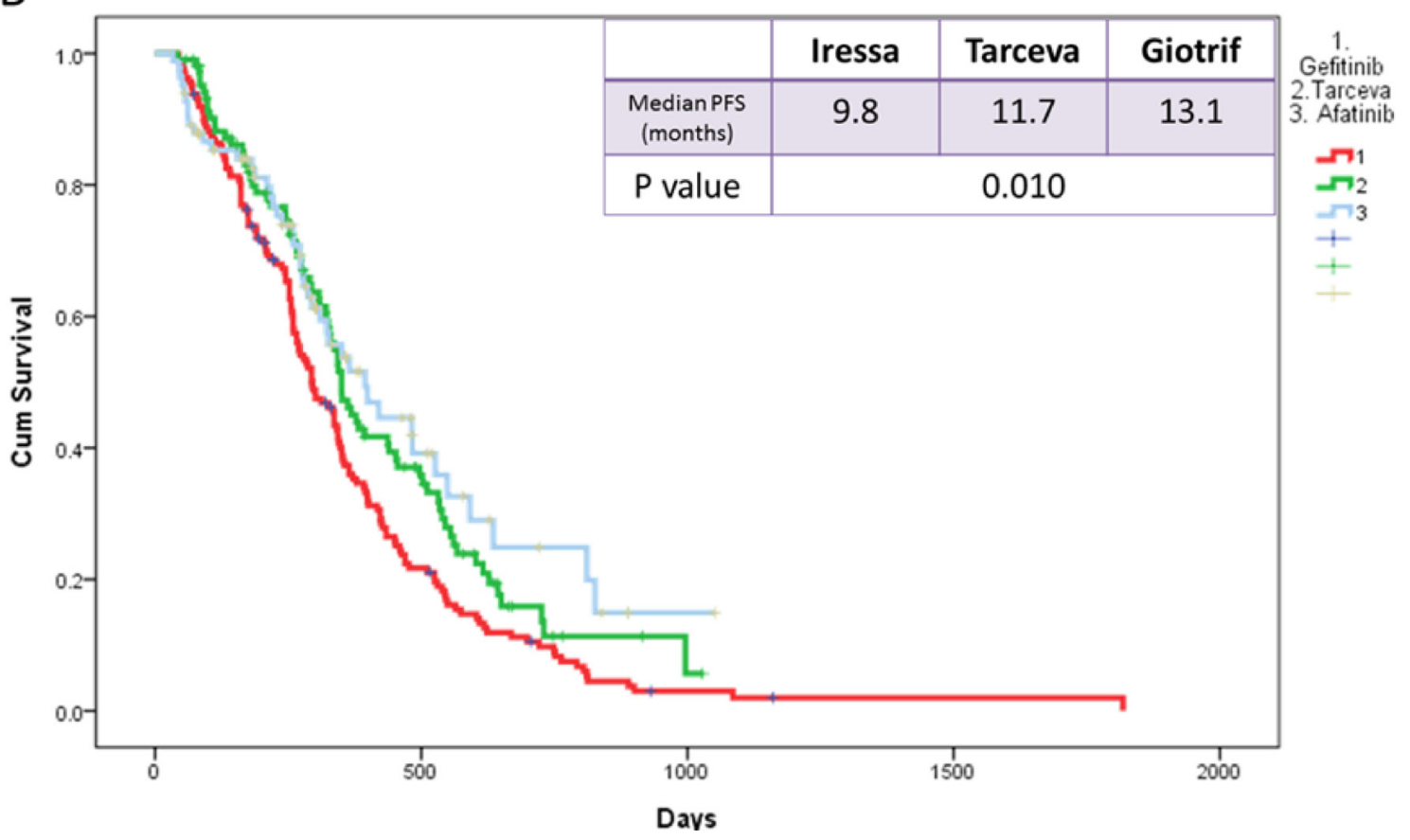

Figure 6: Kaplan-Meier survival curves of progression-free survival in patients who received gefitinib, erlotinib, and afatinib (A) in brain metastasis and (B) in no brain metastasis. 
variable depending on the mutation. G719X, 19 insertions, S768I, and L861Q may be sensitizing mutations [31, 32, 35] and de-novo Thr790Met and exon 20 insertion mutations are resistant mutations [36, 37]. Finally, we only used PFS to evaluate the efficacy of these three major EGFR-TKIs. We did not analyze the OS and the AEs of each arm. OS can be influenced by several factors, and skin rash and grade $\geq 3$ diarrhea were more frequent with afatinib, while hepatotoxicity was more frequent with gefitinib [38]. PFS was evaluated dependent on our real-world practice with a tolerable dose of these drugs.

Afatinib may be the optimal EGFR-TKI in patients with advanced lung adenocarcinoma harboring EGFRactivating mutation, particularly in the absence of BM. Afatinib afforded potentially longer PFS in patients with exon 19 deletions and rare EGFR mutations. Reducing the afatinib dose to $30 \mathrm{mg}$ does not affect its efficacy or the patient PFS. However, future prospective studies are warranted to determine the most appropriate EGFR-TKI for patients with NSCLC harboring EGFR mutations.

\section{PATIENTS AND METHODS}

The study was performed retrospectively between January 2013 and March 2017 at the department of the Division of Pulmonary and Critical Care Medicine,
China Medical University Hospital, which is a 2,146bed community-based university hospital in Taichung, Taiwan. The study was approved by the China Medical University Hospital Internal Review Board (CMUH103REC1-112), and written informed consent was obtained from all patients.

\section{Enrolled patients and clinical data}

The patients inclusion criteria were as follows: (1) age $>18$ years, (2) initial or recurrent stage IIIb or IV lung adenocarcinoma (as classified according to the American Joint Committee on Cancer AJCC TNM staging system, 7th edition) that had been diagnosed at $\mathrm{CMUH}$ between January 2013 and March 2017, (3) positive for EGFR mutation, and (4) received first-line EGFR-TKI (gefitinib, erlotinib, or afatinib). All relevant patient data were collected, including age, sex, smoking history, body mass index, types of EGFR mutations, types of EGFRTKIs, clinical stage, and brain scan image.

\section{Diagnosis and treatment}

Lung cancer was diagnosed via bronchoscopy, computed tomography (CT)-guided or ultrasound-guided lung biopsy, surgery, and malignant pleural effusion cytology. EGFR mutation was analyzed in patients

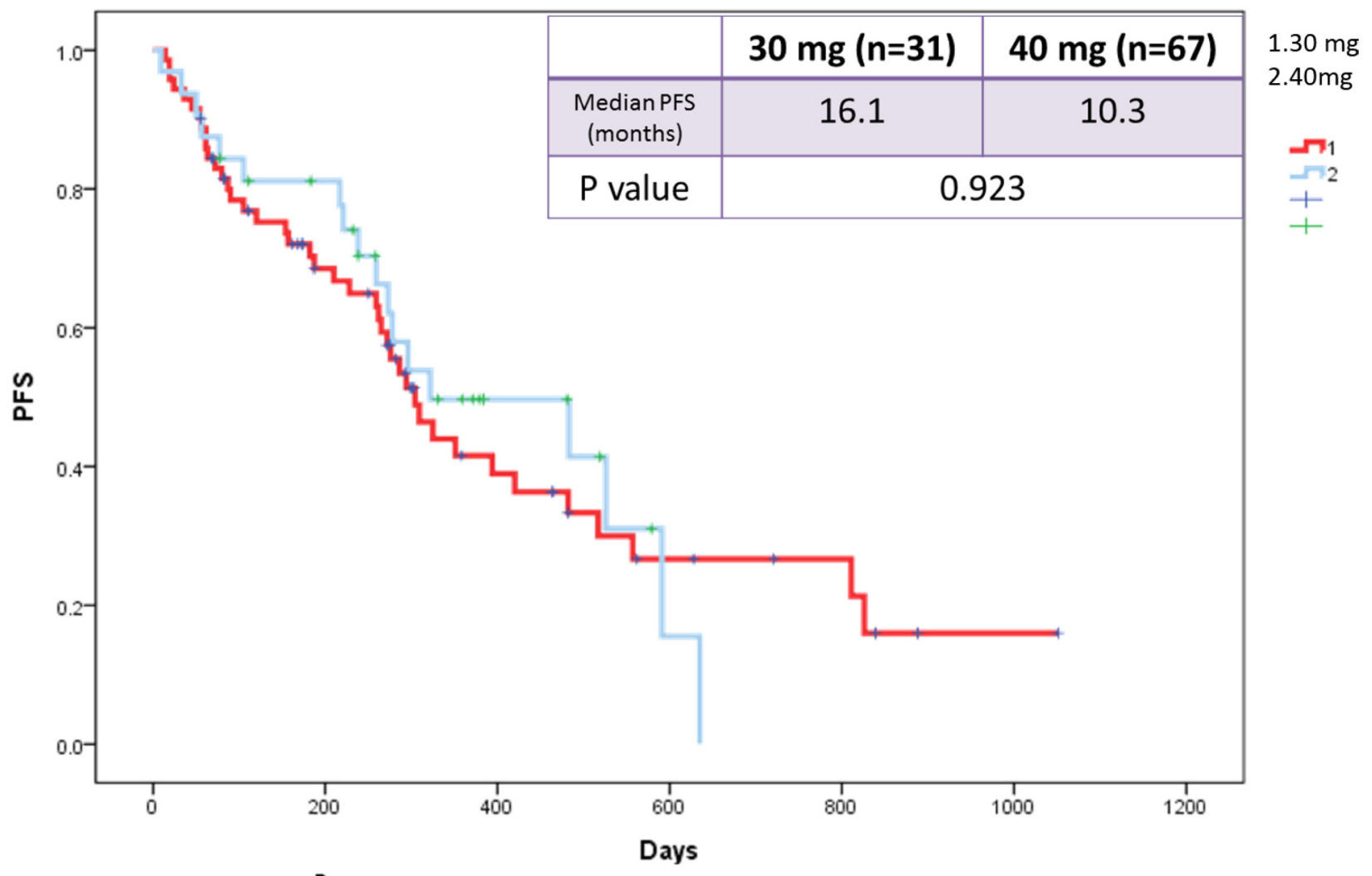

Figure 7: Kaplan-Meier survival curves of progression-free survival in patients who received afatinib doses of $30 \mathrm{mg}$ and $40 \mathrm{mg}$. 
diagnosed with advanced NSCLC. DNA was extracted from formalin-fixed tumor tissue or tumor cells obtained during the diagnostic or therapeutic procedure. EGFR gene mutations were tested via direct sequencing with routine realtime polymerase chain reaction procedures or the amplification refractory mutation system [39]. In Taiwan, three EGFR-TKIs, namely, gefitinib, erlotinib, and afatinib, are reimbursed by the National Health Insurance program as first-line treatment of patients with EGFR mutation-positive NSCLC.

EGFRTKIs were administered orally at a daily dose of $250 \mathrm{mg}$ for gefitinib, $150 \mathrm{mg}$ for erlotinib, and $40 \mathrm{mg}$ for afatinib. Skin rash, stomatitis, paronychia, and diarrhea were common side effects during therapy. If intolerable treatment toxicity occurred, we reduced the amount of EGFRTKIs to the recommended dose. The treatment toxicity was assessed using the Common Toxicity Criteria scale (version 4.0). Treatment was continued until unacceptable toxicity or disease progression, and the patients received chemotherapy or palliative radiotherapy after stopping EGFR-TKIs.

\section{Assessments}

PFS was defined as the date of initiating TKI treatment to the earliest sign of disease progression or death. Disease progression was determined using the Response Evaluation Criteria in Solid Tumors [40] in terms of complete response, partial response, stable disease, and progressive disease. The evaluation was performed via $\mathrm{CT}$ every three months as a routine clinical procedure as per the regulations of the National Health Insurance in Taiwan or other imaging methods (e.g., chest radiography, brain magnetic resonance imaging, bone scan, or positron emission tomography-CT) as needed during EGFR-TKI treatment. Both the physician and radiologist participated in the discussion of the disease progression to develop a proper treatment plan for the patients.

\section{Statistical analysis}

Data were analyzed using SPSS for Windows, version 17.0 (Chicago, IL, USA). Continuous variables were reported as means \pm standard deviations and were compared using two-tailed Student's $t$ tests. Categorical variables were reported as the numbers of patients and percentages. Differences between categorical variables were evaluated using Chi-square or Fisher's exact test. The Kaplan-Meier method was used to generate PFS curves. The log-rank test was used to compare survival curves among patient groups. We used Cox proportional hazards models to adjust variations in the baseline characteristics. All statistical tests were two sided; a $p$ value $<0.05$ was considered significant.

\section{CONFLICTS OF INTEREST}

\section{REFERENCES}

1. Lynch TJ, Bell DW, Sordella R, Gurubhagavatula S, Okimoto RA, Brannigan BW, Harris PL, Haserlat SM, Supko JG, Haluska FG, Louis DN, Christiani DC, Settleman J, et al. Activating mutations in the epidermal growth factor receptor underlying responsiveness of nonsmall-cell lung cancer to gefitinib. N Engl J Med. 2004; 350:2129-2139.

2. D'Angelo SP, Pietanza MC, Johnson ML, Riely GJ, Miller VA, Sima CS, Zakowski MF, Rusch VW, Ladanyi M, Kris MG. Incidence of EGFR exon 19 deletions and L858R in tumor specimens from men and cigarette smokers with lung adenocarcinomas. J Clin Oncol. 2011; 29:2066-2070.

3. Marchetti A, Martella C, Felicioni L, Barassi F, Salvatore S, Chella A, Camplese PP, Iarussi T, Mucilli F, Mezzetti A, Cuccurullo F, Sacco R, Buttitta F. EGFR mutations in nonsmall-cell lung cancer: analysis of a large series of cases and development of a rapid and sensitive method for diagnostic screening with potential implications on pharmacologic treatment. J Clin Oncol. 2005; 23:857-865.

4. Zhou C, Wu YL, Chen G, Feng J, Liu XQ, Wang C, Zhang S, Wang J, Zhou S, Ren S, Lu S, Zhang L, Hu C, et al. Erlotinib versus chemotherapy as first-line treatment for patients with advanced EGFR mutation-positive non-smallcell lung cancer (OPTIMAL, CTONG-0802): a multicentre, open-label, randomised, phase 3 study. Lancet Oncol. 2011; 12:735-742.

5. Fukuoka M, Wu YL, Thongprasert S, Sunpaweravong P, Leong SS, Sriuranpong V, Chao TY, Nakagawa K, Chu DT, Saijo N, Duffield EL, Rukazenkov Y, Speake G, et al. Biomarker analyses and final overall survival results from a phase III, randomized, open-label, first-line study of gefitinib versus carboplatin/paclitaxel in clinically selected patients with advanced non-small-cell lung cancer in Asia (IPASS). J Clin Oncol. 2011; 29:2866-2874.

6. Shi Y, Au JS, Thongprasert S, Srinivasan S, Tsai CM, Khoa MT, Heeroma K, Itoh Y, Cornelio G, Yang PC. A prospective, molecular epidemiology study of EGFR mutations in Asian patients with advanced non-small-cell lung cancer of adenocarcinoma histology (PIONEER). J Thorac Oncol. 2014; 9:154-162.

7. Chan BA, Hughes BG. Targeted therapy for non-small cell lung cancer: current standards and the promise of the future. Transl Lung Cancer Res. 2015; 4:36-54.

8. Solca F, Dahl G, Zoephel A, Bader G, Sanderson M, Klein C, Kraemer O, Himmelsbach F, Haaksma E, Adolf GR. Target binding properties and cellular activity of afatinib (BIBW 2992), an irreversible ErbB family blocker. J Pharmacol Exp Ther. 2012; 343:342-350.

9. Rosell R, Carcereny E, Gervais R, Vergnenegre A, Massuti B, Felip E, Palmero R, Garcia-Gomez R, Pallares C, Sanchez JM, Porta R, Cobo M, Garrido P, et al. Erlotinib versus standard chemotherapy as first-line treatment for European patients with advanced EGFR mutation-positive 
non-small-cell lung cancer (EURTAC): a multicentre, open-label, randomised phase 3 trial. Lancet Oncol. 2012; 13:239-246.

10. Wu YL, Zhou C, Liam CK, Wu G, Liu X, Zhong Z, Lu S, Cheng Y, Han B, Chen L, Huang C, Qin S, Zhu Y, et al. First-line erlotinib versus gemcitabine/cisplatin in patients with advanced EGFR mutation-positive non-small-cell lung cancer: analyses from the phase III, randomized, open-label, ENSURE study. Ann Oncol. 2015; 26:1883-1889.

11. Mok TS, Wu YL, Thongprasert S, Yang CH, Chu DT, Saijo N, Sunpaweravong P, Han B, Margono B, Ichinose Y, Nishiwaki Y, Ohe Y, Yang JJ, et al. Gefitinib or carboplatinpaclitaxel in pulmonary adenocarcinoma. N Engl J Med. 2009; 361:947-957.

12. Mitsudomi T, Morita S, Yatabe Y, Negoro S, Okamoto I, Tsurutani J, Seto T, Satouchi M, Tada H, Hirashima T, Asami K, Katakami N, Takada M, et al. Gefitinib versus cisplatin plus docetaxel in patients with non-small-cell lung cancer harbouring mutations of the epidermal growth factor receptor (WJTOG3405): an open label, randomised phase 3 trial. Lancet Oncol. 2010; 11:121-128.

13. Inoue A, Kobayashi K, Maemondo M, Sugawara S, Oizumi $\mathrm{S}$, Isobe $\mathrm{H}$, Gemma A, Harada M, Yoshizawa H, Kinoshita I, Fujita Y, Okinaga S, Hirano H, et al. Updated overall survival results from a randomized phase III trial comparing gefitinib with carboplatin-paclitaxel for chemo-naive nonsmall cell lung cancer with sensitive EGFR gene mutations (NEJ002). Ann Oncol. 2013; 24:54-59.

14. Maemondo M, Inoue A, Kobayashi K, Sugawara S, Oizumi $\mathrm{S}$, Isobe $\mathrm{H}$, Gemma A, Harada M, Yoshizawa H, Kinoshita I, Fujita Y, Okinaga S, Hirano H, et al. Gefitinib or chemotherapy for non-small-cell lung cancer with mutated EGFR. N Engl J Med. 2010; 362:2380-88.

15. Yang JC, Hirsh V, Schuler M, Yamamoto N, O'Byrne KJ, Mok TS, Zazulina V, Shahidi M, Lungershausen J, Massey D, Palmer M, Sequist LV. Symptom control and quality of life in LUX-Lung 3: a phase III study of afatinib or cisplatin/pemetrexed in patients with advanced lung adenocarcinoma with EGFR mutations. J Clin Oncol. 2013; 31:3342-3350.

16. Wu YL, Zhou C, Hu CP, Feng J, Lu S, Huang Y, Li W, Hou M, Shi JH, Lee KY, Xu CR, Massey D, Kim M, et al. Afatinib versus cisplatin plus gemcitabine for first-line treatment of Asian patients with advanced non-small-cell lung cancer harbouring EGFR mutations (LUX-Lung 6): an open-label, randomised phase 3 trial. Lancet Oncol. 2014; 15:213-222.

17. Yang JCH, Wu YL, Schuler M, Sebastian M, Popat S, Yamamoto N, Zhou C, Hu CP, O'Byrne K, Feng J, Lu S, Huang Y, Geater SL, et al. Afatinib versus cisplatinbased chemotherapy for EGFR mutation-positive lung adenocarcinoma (LUX-Lung 3 and LUX-Lung 6): analysis of overall survival data from two randomised, phase 3 trials. Lancet Oncol. 2015; 16:141-151.
18. Urata Y, Katakami N, Morita S, Kaji R, Yoshioka H, Seto T, Satouchi M, Iwamoto Y, Kanehara M, Fujimoto D, Ikeda N, Murakami H, Daga H, et al. Randomized Phase III Study Comparing Gefitinib With Erlotinib in Patients With Previously Treated Advanced Lung Adenocarcinoma: WJOG 5108L. J Clin Oncol. 2016; 34:3248-3257.

19. Yang JJ, Zhou Q, Yan HH, Zhang XC, Chen HJ, Tu HY, Wang Z, Xu CR, Su J, Wang BC, Jiang BY, Bai XY, Zhong WZ, et al. A phase III randomised controlled trial of erlotinib vs gefitinib in advanced non-small cell lung cancer with EGFR mutations. Br J Cancer. 2017; 116:568-574.

20. Park K, Tan EH, O'Byrne K, Zhang L, Boyer M, Mok T, Hirsh V, Yang JC, Lee KH, Lu S, Shi Y, Kim SW, Laskin J, et al. Afatinib versus gefitinib as first-line treatment of patients with EGFR mutation-positive non-small-cell lung cancer (LUX-Lung 7): a phase 2B, open-label, randomised controlled trial. Lancet Oncol. 2016; 17:577-589.

21. Paz-Ares L, Tan EH, O'Byrne K, Zhang L, Hirsh V, Boyer M, Yang JC, Mok T, Lee KH, Lu S, Shi Y, Lee DH, Laskin $\mathrm{J}$, et al. Afatinib versus gefitinib in patients with EGFR mutation-positive advanced non-small-cell lung cancer: overall survival data from the phase IIb LUX-Lung 7 trial. Ann Oncol. 2017; 28:270-277.

22. Kuan FC, Li SH, Wang CL, Lin MH, Tsai YH, Yang CT. Analysis of progression-free survival of first-line tyrosine kinase inhibitors in patients with non-small cell lung cancer harboring leu858Arg or exon 19 deletions. Oncotarget. 2017; 8:1343-1353. http://doi.org/10.18632/ oncotarget. 13815 .

23. Krawczyk P, Kowalski DM, Ramlau R, Kalinka-Warzocha E, Winiarczyk K, Stencel K, Powrózek T, Reszka K, Wojas-Krawczyk K, Bryl M, Wójcik-Superczyńska M, Głogowski M, Barinow-Wojewódzki A, et al. Comparison of the effectiveness of erlotinib, gefitinib, and afatinib for treatment of non-small cell lung cancer in patients with common and rare EGFR gene mutations. Oncol Lett. 2017; 13:4433-4444.

24. Iuchi T, Shingyoji M, Sakaida T, Hatano K, Nagano O, Itakura M, Kageyama H, Yokoi S, Hasegawa Y, Kawasaki $\mathrm{K}$, Iizasa T. Phase II trial of gefitinib alone without radiation therapy for Japanese patients with brain metastases from EGFR-mutant lung adenocarcinoma. Lung Cancer. 2013; 82:282-287.

25. Porta R, Sanchez-Torres JM, Paz-Ares L, Massutí B, Reguart N, Mayo C, Lianes P, Queralt C, Guillem V, Salinas $\mathrm{P}$, Catot S, Isla D, Pradas A, et al. Brain metastases from lung cancer responding to erlotinib: the importance of EGFR mutation. Eur Respir J. 2011; 37:624-631.

26. Schuler M, Wu YL, Hirsh V, O'Byrne K, Yamamoto N, Mok T, Popat S, Sequist LV, Massey D, Zazulina V, Yang JC. First-Line Afatinib versus Chemotherapy in Patients with Non-Small Cell Lung Cancer and Common Epidermal Growth Factor Receptor Gene Mutations and Brain Metastases. J Thorac Oncol. 2016; 11:380-390. 
27. Won YW, Han JY, Lee GK, Park SY, Lim KY, Yoon KA, Yun T, Kim HT, Lee JS. Comparison of clinical outcome of patients with non-small-cell lung cancer harbouring epidermal growth factor receptor exon 19 or exon 21 mutations. J Clin Pathol. 2011; 64:947-952.

28. Sun JM, Won YW, Kim ST, Kim JH, Choi YL, Lee J, Park YH, Ahn JS, Park K, Ahn MJ. The different efficacy of gefitinib or erlotinib according to epidermal growth factor receptor exon 19 and exon 21 mutations in Korean nonsmall cell lung cancer patients. J Cancer Res Clin Oncol. 2011; 137:687-694.

29. Jackman DM, Yeap BY, Sequist LV, Lindeman N, Holmes AJ, Joshi VA, Bell DW, Huberman MS, Halmos B, Rabin MS, Haber DA, Lynch TJ, Meyerson M, et al. Exon 19 deletion mutations of epidermal growth factor receptor are associated with prolonged survival in non-small cell lung cancer patients treated with gefitinib or erlotinib. Clin Cancer Res. 2006; 12:3908-3914.

30. Zhang Y, Sheng J, Kang S, Fang W, Yan Y, Hu Z, Hong S, Wu X, Qin T, Liang W, Zhang L. Patients with exon 19 deletion were associated with longer progression-free survival compared to those with L858R mutation after firstline EGFR-TKIs for advanced non-small cell lung cancer: a meta-analysis. PLoS One. 2014; 9:e107161.

31. Chiu CH, Yang CT, Shih JY, Huang MS, Su WC, Lai RS, Wang CC, Hsiao SH, Lin YC, Ho CL, Hsia TC, Wu MF, Lai CL, et al. Epidermal Growth Factor Receptor Tyrosine Kinase Inhibitor Treatment Response in Advanced Lung Adenocarcinomas with G719X/L861Q/S768I Mutations. J Thorac Oncol. 2015; 10:793-799.

32. Yang JCH, Sequist LV, Geater SL, Tsai CM, Mok TS, Schuler M, Yamamoto N, Yu CJ, Ou SH, Zhou C, Massey D, Zazulina V, Wu YL. Clinical activity of afatinib in patients with advanced non-small-cell lung cancer harbouring uncommon EGFR mutations: a combined post-hoc analysis of LUX-Lung 2, LUX-Lung 3, and LUX-Lung 6. Lancet Oncol. 2015; 16:830-838.

33. Califano R, Tariq N, Compton S, Fitzgerald DA, Harwood CA, Lal R, Lester J, McPhelim J, Mulatero C, Subramanian
S, Thomas A, Thatcher N, Nicolson M. Expert Consensus on the Management of Adverse Events from EGFR Tyrosine Kinase Inhibitors in the UK. Drugs. 2015; 75:1335-1348.

34. Yang JC, Sequist LV, Zhou C, Schuler M, Geater SL, Mok T, Hu CP, Yamamoto N, Feng J, O'Byrne K, Lu S, Hirsh $\mathrm{V}$, Huang Y, et al. Effect of dose adjustment on the safety and efficacy of afatinib for EGFR mutation-positive lung adenocarcinoma: post hoc analyses of the randomized LUX-Lung 3 and 6 trials. Ann Oncol. 2016; 27:2103-2110.

35. Castellanos E, Feld E, Horn L. Driven by Mutations: The Predictive Value of Mutation Subtype in EGFR-Mutated Non-Small Cell Lung Cancer. J Thorac Oncol. 2017; 12:612-623.

36. Naidoo J, Sima CS, Rodriguez K, Busby N, Nafa K, Ladanyi M, Riely GJ, Kris MG, Arcila ME, Yu HA. Epidermal growth factor receptor exon 20 insertions in advanced lung adenocarcinomas: Clinical outcomes and response to erlotinib. Cancer. 2015; 121:3212-3220.

37. Yu HA, Arcila ME, Hellmann MD, Kris MG, Ladanyi M, Riely GJ. Poor response to erlotinib in patients with tumors containing baseline EGFR T790M mutations found by routine clinical molecular testing. Ann Oncol. 2014; 25:423-428.

38. Takeda M, Okamoto I, Nakagawa K. Pooled safety analysis of EGFR-TKI treatment for EGFR mutation-positive nonsmall cell lung cancer. Lung Cancer. 2015; 88:7-9.

39. Shaozhang Z, Ming Z, Haiyan P, Aiping Z, Qitao Y, Xiangqun S. Comparison of ARMS and direct sequencing for detection of EGFR mutation and prediction of EGFRTKI efficacy between surgery and biopsy tumor tissues in NSCLC patients. Med Oncol. 2014; 31:926.

40. Therasse P, Arbuck SG, Eisenhauer EA, Wanders J, Kaplan RS, Rubinstein L, Verweij J, Van Glabbeke M, van Oosterom AT, Christian MC, Gwyther SG. New guidelines to evaluate the response to treatment in solid tumors. European Organization for Research and Treatment of Cancer, National Cancer Institute of the United States, National Cancer Institute of Canada. J Natl Cancer Inst. 2000; 92:205-216. 